\title{
Sustainability Science
}

\section{How pragmatism in environmental science and policy can undermine sustainability transformations: the case of marginalized mountain areas under climate and land use change}

\author{
Simo Sarkki (Corresponding author) \\ Cultural Anthropology, Faculty of Humanities, PO Box 1000 \\ FIN90014 University of Oulu, Finland \\ Email: $\underline{\text { simo.sarkki@oulu.fi }}$ \\ Phone: +358405104149
}

\begin{abstract}
Andrej Ficko
University of Ljubljana, Biotechnical Faculty, Department of Forestry and

Renewable Forest Resources, Vecna pot 83, 1000 Ljubljana, Slovenia

Email: Andrej.Ficko@bf.uni-lj.si
\end{abstract}

\author{
Karsten Grunewald \\ Leibniz-Institute of Ecological Urban and Regional Development, \\ Weberplatz 1, 01217 Dresden, Germany \\ Email: k.grunewald@ioer.de
}

Apostolos P. Kyriazopoulos

Department of Forestry and Management of the Environment and Natural Resources,

Democritus University of Thrace, 193 Pantazidou str., 68200 Orestiada, Greece

Email: apkyriaz@fmenr.duth.gr

\section{Maria Nijnik}

Social, Economic and Geographical Sciences Group, The James Hutton Institute

Craigiebuckler, Aberdeen, AB158QH, Scotland, UK

Email: maria.nijnik@hutton.ac.uk 


\begin{abstract}
Global warming, land use change, mass tourism and a deteriorating socio-economic situation pose serious threats to the sustainability of mountain areas. The future development of these areas could be an example of the Great Transition scenario. Based on iterative and collaborative discussions with 60 treeline experts, we 1) envisioned plausible futures of treeline ecosystems in Europe and 2) explored the role of pragmatism in scenario development and use. The three global change scenario classes (Conventional Worlds, Barbarization and Great Transitions) and four European scenarios (Economy First, Fortress Europe, Policy Rules, Sustainability Eventually) were downscaled using the drivers-pressures-state-impact-response (DPSIR)
\end{abstract} framework. The scenarios that emerged, i.e. Global Markets, Self-sufficient Economies, Tyranny of Climate Governance and Sustainable Use of Ecosystem Services, show that pragmatism can have either a propitious or pernicious role in scenario analysis. Instead of being truly honest brokers, scenario producers are likely to manipulate, reconstruct and change scientific knowledge to avoid socially and politically undesired trajectories. We showed by mathematical optimization that scenario users are likely to miss the Sustainable Use of Ecosystem Services scenario if they search within the pragmatic decision space which optimally justifies the two pre-existing global policies: climate policy and economic growth. We conclude that pernicious pragmatism leads to "the trap of the day" - a tendency of both users and producers of scenarios to use pre-existing policy agendas and scientific narratives as a pretext to promote their own objectives instead of being open to transformation in science and policy.

Keywords: Climate Change; DPSIR; Ecosystem Services; Exploratory qualitative scenarios; Land use; Science-policy interactions. 


\section{Introduction}

Much of the global debate on the possible futures of social-ecological systems is concentrated around human well-being and environmental sustainability and the major driving forces and critical uncertainties associated with them (MA 2005). Reflection on the current challenges and transformative actions needed to address these questions has led to the identification of a number of possible alternative development paths (Raskin et al. 2002; MA 2005; IPCC 2014; Kishita et al. 2016). A promising approach to explore futures linked to sustainable development (O’Neill et al. 2015) is by developing scenarios. Scenarios are "renderings of plausible possibilities which are designed to stretch the imagination, stimulate debate and, by warning of pitfalls ahead, prompt corrective action" (Raskin et al. 2010: 2627). They are not a prognosis for the future, but rather plausible and relevant stories about how the future might unfold, accounting for critical uncertainties (Raskin et al. 2005). Coherent scenario storylines follow the internal scenario logics and explore consequences of uncertainties regarding the development of key driving forces (Zurek and Henrichs 2007).

In exploring alternative futures several approaches are possible depending on the scale of research and the aim of scenario building. Large-scale scenario assessments envision possible changes in the major global drivers, such as economies, human population growth, energy use, technological advancement and climate change. They have been conducted among others by the Intergovernmental Panel on Climate Change (IPCC 2014); UNEP (2007), Millennium Ecosystem Assessment (MA 2005), Tellus Institute (2016) and the Great Transition Initiative (http://www.greattransition.org/). Global 
change scenarios have certainly been instrumental for illuminating the possible state of civilization and the environment in the future, but globalized discourse may neglect context-specific dynamics at the local level (Kok et al. 2016; Turnhout et al. 2016) or in vulnerable social-ecological systems. The scenario development literature has frequently faced challenges in combining global perspectives with issues unique to the regional or local scale (Zurek and Henrichs 2007). "Glocal” thinking (Roudometof 2015) seems to be best suited for the exploration of multi-dimensional and multi-level decision contexts.

\begin{abstract}
With regard to the aim of scenario building, two major approaches have become established in scenario analysis. Normative "backcasting" scenarios search for feasible trajectories to achieve the desired state. Exploratory scenarios, on the other hand, describe one or more trajectories the system may follow if "left to itself" or under alternative sets of initial conditions (Gallopin 2015) while taking into account multiple alternative legitimate states of the future and paths to it (Wilkinson 2009; Vervoort et al. 2014).
\end{abstract}

One fundamental characteristic of exploratory scenarios is that they outline various plausible development paths and their consequences without being policy-prescriptive. The value choice of what to do with the renderings of plausible possibilities is a decision for actors. Governmental, non-governmental and intergovernmental organizations; international corporations; and civil society may have their own interpretation of the scenarios. These actors need the political and corporate will for 
gradually bending the curve of development towards a desirable future (Raskin et al. 2002). However, the reform path may not always be recognized as pragmatic and desirable. Aspirations for a more sustainable world could be in conflict with the interests of global capital for infinite economic growth, although several simulations suggest that growth and globalization are not only undesirable from an environmental point of view but also not feasible from an economic, energy and climate dynamics point of view (Capellan-Perez et al. 2015). On the other hand, in their battle for the environment, intergovernmental organizations and civil society may excessively identify themselves with strict global climate policy, leaving all other local alternative developmental paths aside. Such pernicious pragmatism leads the scenario users to support scenarios that are based on the pragmatic experiences of current paradigms and situations rather than truly free deliberation on the future (see Dewey 1929; Hildebrand 2003; Gutek 2014), which diminishes options for adopting scenarios other than those high on the current policy agenda.

\footnotetext{
Also, scenario producers may be tempted by pragmatism, as they are expected to create and communicate a compelling narrative that engages users. In communicating scenarios to actors, honest brokering of various policy alternatives has been one of the most powerful approaches to enhance the relationship between science and policy (Pielke 2007; Striling 2010). However, facts may not always be free from values, and since scenarios can have simultaneous positive and negative implications for sustainable development, they open up space for the pragmatic behavior of scenario producers to promote the scenario that best fits into pre-existing policy agendas (see Latour 1987; Van der Sluijs 2005). Scenario producers also use other strategies in their rhetoric to
} 
transform existing scientific knowledge into knowledge usable for policy makers and stakeholders, such as "reduction" and "rhetorical packaging" (Boezeman 2016). "Reduction" aims to narrow down the topic under examination to a level that can be handled in a credible way, while "rhetorical packaging" is used to make compelling arguments as to why a particular scientific discipline is the best source of trustworthy knowledge (Boezeman 2016). Overly pragmatic utilization of such strategies can transform honest brokering into "stealth issue advocacy", which seems a value neutral strategy at a first sight, but promotes certain (hidden) agendas (see Pielke 2007). However, the value choices may be invisible even for the scenario producers themselves. Pragmatism in scenario production maximizes self-interest, objectives and power in order to support pre-existing and positioned objectives and paradigms at the expense of openness to great transitions (see Goodin 2010; Beck 2012).

This paper explores how pragmatism in science and policy may replace honest brokering in developing, communicating and using exploratory scenarios. Using scenarios of the European treeline areas as an example, we 1) analyzed how global climate policy and economic growth imperatives on the one hand, and visioning as a method for producing the consensual and compelling scenarios (Moore et al. 1999) on the other hand, open up space for the pragmatic behavior of both scenario users and producers and 2) proposed a framework for assessing and quantifying the pragmatism of scenario users. It is argued that pre-existing policy objectives and scientific approaches narrow down the creative capacities of actors, leading to "the trap of the day". 


\section{Materials and methods}

\subsection{Scenario production}

The threat of "the trap of the day" is exemplified in the scenarios of European treeline areas. Ecosystems at or near treelines are one of the early detectors of global change (e.g. Kupfer and Cairns 1996). Defined as ecosystems at the line connecting the uppermost or northernmost patches of trees in alpine and arctic forests below heathland and grassland (Holtmeier 2009), they have long been considered as evidence of a warming climate and anthropogenic pressures (Mountain Agenda 2002). Sarkki et al. (2016: 2020) extended the ecological definition of a treeline to "treeline-related administrative areas, and associated landscapes and ecosystems" to emphasize the embeddedness of a treeline in the broader context of social-political factors.

Our scenario development started with existing stylized global story lines (i.e. Conventional Worlds, Barbarization and Great Transitions, Raskin et al. 2002) and European scenarios (i.e. Economy First, Fortress Europe, Policy Rules, Sustainability Eventually) (UNEP 2007; Kok et al. 2011), which were relabeled and downscaled to account for specific issues relating to the treeline areas. The three stylized global story lines and four European scenarios reflect diverse developments, such as economic growth, national security and self-sufficiency, climate change mitigation and sustainable use of ecosystem services, which might have divergent impacts on treeline areas. 
The large-scale scenarios were downscaled through iterative and collaborative discussions with around 60 experts from nine European mountain regions and the Caucasus (EEA 2010, Fig. 1) in seven two-day meetings of the SENSFOR project (Enhancing the resilience capacity of SENSitive mountain FORest ecosystems under environmental change). The downscaling took into account the previous work of the SENSFOR project in 41 case studies (Fig. 1) on the drivers-pressures-state-impactresponse (DPSIR) factors (Kyriazopoulos et al. 2014), stakeholder needs regarding ecosystem services (Sarkki et al. 2016) and assessment of good governance in European treeline areas (Sarkki et al. 2015). A draft of four scenario storylines was presented to the SENSFOR members at the project meeting in February 2016, where the participants were encouraged to come up with additional elements of scenarios associated with political, economic, social and technological (PEST) dimensions of the future (Healey 1994).

Fig. 1. Europe's mountain massifs with the number of case studies used for the development of the treeline area scenarios (adapted after EEA 2010).

We followed the methodology for developing exploratory scenario storylines in six steps as follows (Henrichs et al. 2010; Kok et al. 2011; Fig. 2): 1) We discussed the current state of European treeline areas. 2) We discussed the main uncertainties about the future of European treeline areas with respect to anthropogenic global warming and land use change as the two main direct pressures (Kyriazopoulos et al. 2014). 3) We linked key uncertainties to existing global change scenarios (Table 1). 4) We discussed 
the scope and limitations of the scenarios with regard to different developments in European treeline areas. The examined developments were as follows: i) the expansion of unregulated global markets; ii) increasing national and European self-sufficiency in raw materials, energy and food production; iii) the extent of climate change mitigation; and iv) sustainable use of ecosystem services. 5) We developed storylines based on key uncertainties and existing scenario logics. To focus on treeline area specifics we selected the sub-themes that link to land use and climate change pressures as the most relevant for European treeline areas (Kullman and Øberg 2009; Smith et al. 2009). The themes included transport, food production, subsidies, energy supply, governance and policy, the role of science in governance, markets, general attitude to environmental problems and the perception of treeline areas. 6) We envisioned the possible impacts of the scenarios on European treeline areas with regard to these themes (Electronic Supplementary Material S1-S4).

To understand the potential impacts of global and regional change drivers on European treeline areas, we applied the DPSIR framework (e.g. Rounsevell et al. 2010). Knowing the social-ecological conditions in European treeline areas and being aware of the internal logics of each of the presented scenarios, we summarized the positive and negative points of each of the four scenarios with respect to sustainability (Table 2).

Finally, we assessed the scenarios in a self-reflexive session. Self-reflexivity critically assesses the framings, reductions, generalizations and rhetoric of the paradigms and theories one uses to analyze the empirical materials (Davies 2008). Using the example 
of pastoralism in treeline areas, we illustrated differences between the results of a straightforward DPSIR application and more contextual assessment of pastoralism and land use at the local level using a cognitive map. The cognitive map (see van Vliet et al. 2012) identifies a complex web of related issues that are easily missed when examining environmental change by downscaling and generalizing global storylines and relying only on direct causalities between the DPSIR factors (Figure 4; see Niemeijer \& de Groot 2008).

Fig. 2. The workflow diagram in scenario production and evaluation

\subsection{A framework for assessing the pragmatism of scenario users}

Once the qualitative storylines were developed, we quantified the themes that emerged as the most relevant for European treeline areas in step 5. In the quantification we used the PoleStar System projections for Market Forces, Policy Reform, Fortress World and Great Transition scenarios for Europe until 2050 (Tellus Institute 2016) for the indicators that either corresponded or closely related to our themes (http://www.polestarproject.org/). For instance, to quantify the development of Transport in treeline areas under the scenario of global economic growth, we used the Final Transport Energy Demand indicator from Market Forces, for Food Production we used Agriculture Crop Production, for Energy Supply we used Primary Energy Supply and for Markets we used the Gross Domestic Product per capita based on purchasing power parity (GDPPPP), all calculated as a mean for Eastern and Western Europe projections and as an index relative to 2005 . For the themes not quantified in the 
PoleStar System (i.e. Subsidies, Governance and Policy, Role of Science in Governance, Worldview on Environmental Problems, Treeline Area Perception) we used expert judgment to project their magnitude of change relative to 2005 . This quantification aimed to operationalize the scenarios in a relative sense to show how distant the scenarios are from each other with regard to the indicators rather than to project how a specific indicator will change in the future.

The expected behavior of scenario users was analyzed by constructing the decision space (D) in which any decision of scenario users for the trajectory satisfies the condition that the trajectory does not deviate "too much" from the pre-existing policy agendas and scientific narratives. Identifying the best solution from all feasible solutions that does not violate certain constraints is a typical optimization problem. The identification of the most pragmatic scenario (SPRAGM) could thus be represented as an optimization problem where the two politically dominating but conceptually fundamentally different scenarios by $2050\left(\mathrm{~s}_{\mathrm{i}}\right)$ (i.e. global economic growth and strict climate policy) are considered the two boundaries of $\mathrm{D}$,

$$
\text { supremum }\left(\mathrm{s}_{1}=\sup _{[2005,2050]} D\right)(\text { Eq. 1) and }
$$

infimum $\left(\mathrm{s}_{2}=\inf _{[2005,2050]} D\right),($ Eq. 2)

and the objective function to be minimized (Z, Eq. 3) is the loss function. For the sake of simplicity the loss function was the sum of squares of deviations in the parameters of the SPRAGM by 2050 from the parameters of the $s_{1}$ and $s_{2}$ scenarios over all 9 themes $(t)$ of the scenarios (Table 1): 
$\mathrm{Z}=\min \sum_{t=1}^{9} \sum_{i=1}^{2}\left(s_{P R A G M}-s_{i}\right)^{2}($ Eq. 3)

D containing the most pragmatic scenario in the period $p$ from 2005 to 2050 is thus represented as the area between the supremum and infimum:

$D=\int_{2005}^{2050}\left[s_{1}(p)-s_{2}(p)\right] d p($ Eq. 4$)$

The pragmatic decision space (D') is a subset of $\mathrm{D}$ in which the pragmatic scenario users are likely to start searching for plausible trajectories. We expect that under the doctrine of economism that attaches principal importance to economic growth (e.g. Escobar 2015), the search for the optimal scenario is likely to start near the scenario that attaches greatest importance to market forces and then gradually moves toward the scenario of strict climate policy, but ends in between these two at the most pragmatic scenario SPRAGM.

In the calculation of SPRAGM we used the non-linear solver in the What's Best ${ }^{\circledR}$ package 12 (Lindo Systems Inc. 2012), which uses linear approximations to the problem functions at a number of stages in the solution process.

\section{Results}

\subsection{The scenarios for European treeline areas}

Four scenarios emerged: Global Markets, Self-sufficient Economies, Tyranny of Climate Governance, and Sustainable Use of Ecosystem Services (Table 1). The four scenarios represent the possible futures of treeline areas shaped mainly by 
anthropogenic global warming and land-use change (Fig. 3). Each of the four scenarios has different implications for the economic, ecological, social and cultural dimensions of sustainability (Table 2).

Fig. 3. Four scenarios for the future of European treeline areas ordinated in a climate change - land use matrix

Table 1. Four scenarios of the future of European treeline areas and the key variables describing the scenarios

Table 2. Negative (-) and positive (+) implications of the scenario storylines on the four dimensions of sustainability of European treeline areas

\subsubsection{Global Markets}

The "Global Markets" scenario is characterized by a reactive attitude to environmental problems and climate change mitigation. Food and energy production are located in the cheapest locations, possibly leading to a decrease in land-use intensity in marginal rural areas. The main global driver is neoliberalization of markets (Heyen et al. 2007) leading to a dramatically changed climate (IPCC 2014).

In this scenario the paradigm of economic growth dominates. However, if unregulated markets have negative impacts on other economically productive land uses, compensation schemes may be introduced or synergies considered. Climate change 
worsens and fossil fuels are widely used. As land use intensity in European treeline areas declines, there are no significant direct pressures on treeline ecosystems apart from mass tourism in snow-safe destinations. Electronic Supplementary Material S1 outlines the key pressures and their impacts on treeline areas under this scenario.

\section{S1. Pressures and impacts in the "Global Markets" scenario}

\subsubsection{Self-sufficient Economies}

The "Self-sufficient Economies" scenario is based on the assumption that regionalization instead of globalization drives political decisions and that climate change mitigation measures are inferior to aspirations for local self-sufficient economies. The markets are mainly European as borders are closing due to increasing migration and terrorism threats, and the relationships between western and eastern and developing countries are poor. The need for self-sufficiency leads to extensively subsidized agriculture and pastoralism despite the potentially negative environmental impacts (Schmid et al. 2007).

Self-sufficiency in energy, food and goods production leads to an intensification of land use in treeline areas. Only profitable activities are supported, which means that stakeholders representing minor interests or economically inefficient land uses will have little impact on decision-making. Industrial activities and agriculture are only regulated if they exceed the maximum sustainable yield or threaten other economically important land uses (see Electronic Supplementary Material S2 for details). 


\section{S2. Pressures and impacts in the "Self-sufficient Economies" scenario}

\subsubsection{Tyranny of Climate Governance}

The "Tyranny of Climate Governance" scenario is a global top-down technocratic scenario, where proactive climate change mitigation objectives drive policy and distract political attention from issues other than climate change. Strong climate governance leads to wide ranging, strong and efficient implementation of European and global mitigation policies and measures.

In this scenario climate-neutral energy production dominates (e.g. hydropower, woodbased energy, nuclear power, solar panels and wind turbines). Forests are moderately used to produce biomass as attention is paid to carbon storage. Trade in food decreases due to the negative effects of transportation on climate change, resulting in the intensification of European pastoralism and agriculture. International mass tourism is very low due to a dramatic reduction in air travel. A strong technocratic policy may lead to non-compliance of many sectoral policies, resulting in sanctions. On the other hand, subsidies and economic incentives for climate-neutral and local production of goods and services may gradually result in a more positive attitude to technocratic climate governance. The pressures and their impacts under this scenario are outlined in Electronic Supplementary Material S3. 
S3. Pressures and impacts in the "Tyranny of Climate Governance" scenario

\subsubsection{Sustainable Use of Ecosystem Services}

This scenario combines market measures and regulatory governance to safeguard ecosystem services. It is a proactive scenario that links environmental problems to human well-being. Under this scenario land use in treeline areas is moderate, leading to a balanced use of multi-functional landscapes. The combination of regulatory policies and market-based instruments at multiple levels, including local, is used to enhance sustainability and balanced use of ecosystem services. Previously unrecognized ecosystem services are targeted and governed by developing markets for them. These include hydropower companies' payments to down-stream water users, state payments to private forest owners for practicing retention forestry and payments by tourism entrepreneurs to pastoralists and traditional users to enhance the image of the treeline area as a tourist destination. Global mass tourism is in decline. Renewable energy solutions are developed. Land use effects are systematically monitored and problems are detected at an early stage (Electronic Supplementary Material S4).

S4. Pressures and impacts in the "Sustainable Use of Ecosystem Services" scenario

\subsection{Reflections on scenario production}


The experts focused on commonly recognized and direct implications of climate and land-use change. Alternative drivers, such as human population growth, migration and technological development, were left out of the picture. The scenarios addressed technological development only via greener production, but did not envision its influence on the development of rural treeline areas. Moreover, many single pressures related to land use and climate change were identified, whereas cumulative pressures from climate and land use change and contrasting impacts of various land uses in the same area on the environment and local cultures and livelihoods were not considered. The commonly identified pressure was grazing, with a negative impact on the integrity of treeline areas. This rather generalized assumption separates nature and culture, which does not reflect local realities where pastoralism is often considered as part of the treeline landscape rather than as an external threat.

\footnotetext{
Impacts were limited only to direct impacts to treeline areas with no holistic assessment of impacts on the socio-cultural realm. No possible impacts of diverse and modern free time activities for young people on land abandonment prevention and intergenerational change in pastoralism were identified (Figure 4). The scenarios addressed mainly largescale policies and governance instruments directly linked to nature stewardship, while rural development policies targeting human population viability in remote areas were not considered. Locally initiated self-organized actions were not included.
} 


\section{Figure 4. "Reduction" and "rhetorical packaging" in the DPSIR framework for}

studying treeline area pastoralism (white background) and more contextual mapping of key factors explaining future changes in treeline area pastoralism (grey background). The arrows between boxes illustrate feedbacks that can be positive (+) or negative (-).

\subsection{The pragmatism of scenario users}

Pragmatism in selecting future trajectories of treeline areas favors the trajectories that meet the objectives of the "Global Markets" scenario and in the best case approaches the objectives of climate policy (Fig. 5). However, in trying to minimize a loss of legitimacy in the eyes of the economic sector while moving towards a low-carbon society, scenario users actually search in decision space $\mathrm{D}^{\prime}$. The risk of failure is minimized if SPRAGM is the chosen scenario. The "Sustainable Use of Ecosystem Services" scenario is almost never reached, as the political and financial costs of a fundamental shift in the management paradigm are considered to be too high. Any step away from the two dominating global policy imperatives - global economic growth and strict climate policy - could result in the failure to reach either of them. Policy makers are unlikely to risk losing the legitimacy of their policies against global capital and international bodies for climate governance. The result of such pragmatism is the Business-As-Usual growth trajectory (i.e. the most pragmatic scenario) that is only marginally adapted by alternative visions of the future. 
Fig. 5. Four scenarios for the development of key variables in European treeline areas with the pragmatic space in which the scenario users can choose trajectories that best fit pre-existing policy agendas and scientific narratives and maintain the legitimacy of climate-sensitive and economic growth-oriented policies.

\section{Discussion}

\subsection{Pragmatism in scenario production}

Our study showed that there are several points where knowledge producers may manipulate, reconstruct and change scientific knowledge to reach certain pre-established policy objectives (Nelson et al. 2008). We highlighted "reduction" and "rhetorical packaging" as two capacities of knowledge producers that may also be used perniciously in transforming existing scientific knowledge into that which can be used by policy makers and stakeholders (Boezeman 2016).

There were two interlinked pragmatic "reductions" in our scenario exercise. Turnhout et al. (2016) has made a strong argument about the danger of using a globalized scientific representation of human-environment relationships, especially in the field of climate change, but also increasingly in terms of biodiversity and ecosystem services. Globalized reduction by the application of the DPSIR framework that was used to narrow-down the topic under examination to a level that can be handled in a credible way (Boezeman 2016) assumes simplistic causal relationships between different components of a social-ecological system (Niemeijer \& de Groot 2008). This 
framework, if not adapted to the local context, can only identify factors directly linked to the environment, while indirect factors emerging at the local level remain cursory (Figure 4). In this light, it has been recognized that the utilization of "monological" methodological approaches to assess futures may lead to impartial results which are unaware of the key underlying assumptions of the applied methods (Kaivo-Oja 2016). The scenario literature has tackled the challenges related to reduction and globalizing narratives by developing multiple methods to produce multi-level scenarios, which involve a varying degree of connectedness and enrichment between the levels (Zurek \& Henrichs 2007).

The second reduction of surprises and complexities occurred when the whole spectrum of relevant issues (e.g. art, religion, law, sport, health, education, and the mass media) was truncated to a limited number of dimensions, such as science, policy and economy (Roth and Kaivo-Oja 2015). No interactions between the issues, nor their cumulative impacts, were considered. For example, the Technocratic Tyranny of Climate Governance scenario represents a global view of science and policy. Similarly, the Selfsufficient Economies scenario strongly relates to the aspiration of some national policies in Europe for apartheid economies and societies. The Global Markets scenario inherently assumes that people must have access to global markets in order to succeed in economic terms. However, sustainable use of ecosystems diverges from globalized paths as it is related to locally developed practices (c.f. Adapting Mosaic" in MA 2005). Each of these scenarios has internal logics, which aim to make a given storyline compelling. However, the drive for increased ownership inevitably leads to overexploitation of existing narratives on socio-environmental change and reduces 
complexity and surprising aspects in the scenarios. The reason for such bias may be due to scenario producers' willingness to maximize the impact of their scenarios by making strong connections to existing storylines or "discourse coalitions" (Hajer 1995) considered as mainstream regarding global environmental and social changes and futures.

\section{Envisioning future alternative paths often leads to rhetorical packaging in form of "the usual suspects": the good (Balanced Use of Ecosystem services), the bad (Global Markets), the ugly (Self-sufficient Economies) and the great unknown (Tyranny of Climate Governance). Thus, even though our scenarios are exploratory and not policy} prescriptive, some of them are likely to be implicitly supported over others. We presented the usual suspects, but also illustrated the plausible side effects of top-down climate governance and showed that all the scenarios have positive and negative implications for sustainability (Table 2). In this way we tried to depolarize the clash between the scenarios that focus either on neoliberal markets or environmental sustainability. This polarization often sees a reactive (free markets) vs. proactive (environmental sustainability) relationship to environmental problems as the two interchangeable alternatives (cf. Kok et al. 2011). The result may be a naïve blaming of organizations for environmental "immorality" (cf. Roth 2016). However, preaching cannot enhance environmental sustainability. Rather the opposite, it evokes defenses and a retreat to purely pragmatic decisions.

\subsection{Pragmatism in making the decisions on the future}




\begin{abstract}
Bending the curve of development is often challenging; it is easier to continue with business-as-usual than to implement a change. In addition, an emerging threat, though of short-duration, may quickly provide social license for a fundamental deviation from the chosen path with no return to the long-term optimal trajectory. However, scenario users are unlikely to take the risk of losing their legitimacy and follow the path that seems to satisfy the most influential actors.
\end{abstract}

\begin{abstract}
The detection of such pernicious pragmatism is challenging and has not received much attention. Quantitative methods have been mostly used in scenario development, e.g. for structural analysis, quantifying relations between the variables, consistency analysis, choosing smaller subsets from sets of plausible scenarios, and scenario visualization (e.g. see Carlsson et al. 2015, LIPSOR 2016, Lord et al. 2016 for recent applications). An equally important part of scenario analysis is communication with scenario users and monitoring their progress in sustainability. The proposed framework for detecting and quantifying the pragmatism of scenario users can be used to foster the transformation.
\end{abstract}

\footnotetext{
A strong advantage of our framework in comparison to more theoretical, philosophical and normative critiques of the world trajectories is that we used virtually the same language that organizations in the era of neoliberalism and global capitalism use: optimization. Our hack on pernicious pragmatism is thus not moral and not about a "more or less of the same" (Roth 2016: 11). Rather the opposite, we stimulate the actors to "re-functionalize the growth" (Roth 2016: 3) and reprogram their
} 


\begin{abstract}
"organizational programs" (Roth 2016: 6) "in line with the fact that the economy is only one among many function systems" (Roth 2016: 11). Pernicious pragmatism which searches for the scenario that is optimal for the currently ruling policies can thus gradually transform into a propitious filtering out of the trajectories that are unsustainable for society as a whole.
\end{abstract}

The hypothesized pragmatism of scenario users is, rigorously speaking, a theory which can only be supported or falsified after a certain period of time when the actual trajectory of the treeline area development could be positioned within the pragmatic space D' and analytically paralleled with the SPRAGM trajectory. It is also unlikely that in practice policy-makers behave as utility maximizers who maximize the robustness of their decisions against climate-sensitive or growth-oriented policies for all themes of relevance. For instance, if climate change seriously threatened sufficient food production in mountainous areas, this could result in an extension of the pragmatic decision space D' in the subsidies theme (Fig. 5), and the subsidy policy would be searched for closer to the "Tyranny of Climate Governance" scenario.

\title{
5 Conclusion: "Trap of the day"
}

Scenarios can ideally function at the interface of science and policy and envision future developments. However, envisioning the future and transformations in science and policy may be seriously bound by the pragmatism of pre-existing science and policy. We argue that this leads to the "trap of the day", where transformations are blocked by a strong and pragmatic orientation towards the current state of ecosystems and society 
instead of truly anticipatory explorations of future uncertainties and their consequences. Pernicious pragmatism also decreases actors' creativity, leading to limited anticipation of future development, which does not go beyond simple causalities between global drivers and local impacts. Nevertheless, both scientists and policy makers should try to anticipate futures and adapt, redefine and transform their agendas based on careful deliberation. A potential analgesic for the "trap of the day" - but not a panacea - is the combination of normative backcasting and exploratory scenarios to guide the interpretations of scenario users. The minimum is to be transparent on the underlying policy objectives and causal assumptions, and to accept that the most likely future might collide with the objectives and aspirations at hand, which requires thinking beyond positioned views on today's desirable state.

\section{ACKNOWLEDGEMENTS}

This article is based upon work from COST Action ES1203 SENSFOR, supported by COST (European Cooperation in Science and Technology). Support of the H2020 SIMRA project on Social Innovation in Marginalised Rural Areas, Contract number 677622, provided by the European Commission to the James Hutton Institute and the University of Oulu is acknowledged by Maria Nijnik, the Coordinator. The study is also part of the thematic research carried out at The James Hutton Institute under the Scottish Government's Strategic Research Programme, 2016-2021. We are grateful for the support provided, and to Carol Kyle for proofreading.

\section{References}




\begin{abstract}
Ambrus M, Arts K, Hey E, Raulus H (eds.) (2014) The role of “experts" in international and European decision-making processes: Advisors, decision makers or irrelevant actors? Cambridge University Press, United Kingdom.
\end{abstract}

Beck S (2012) Between tribalism and trust: The IPCC under the "Public Microscope'”. Nat Cult 7:151-173. doi:10.3167/nc.2012.070203

Boezeman D (2016) Understanding the transformation of climate futures. A conceptual framework illustrated with urban adaptation policy. Futures 76:30-41.

doi:10.1016/j.futures.2015.07.008

Capellan-Perez I, Mediavilla M, de Castro C, Carpintero O, Miguel LJ (2015) More growth? An unfeasible option to overcome critical energy constraints and climate change. Sust Sci 10: 397-411. doi:10.1007/s11625-015-0299-3

Carlsson J, Eriksson LO, Öhman K, Nordström E-M (2015) Combining scientific and stakeholder knowledge in future scenario development - A forest landscape case study in northern Sweden. Forest Policy and Economics 61: 122-134. doi:10.1016/j.forpol.2015.08.008

Davies CA (2008) Reflexive Ethnography: a guide to researching selves and others. 2nd edition. London, New York, Routledge.

Dewey J (1929) The Quest for Certainty: A Study of the Relation of Knowledge and Action, Minton, Balch, and Company, New York, NY. Reprinted, pp. 1-254 in John Dewey, The Later Works, 1925-1953, Volume 4: 1929, Boydston JA (ed), Simon HF (text ed), Toulmin S (intro), Southern Illinois University Press, Carbondale and Edwardsville, IL, 1984 
Drexler C, Braun V, Christie D, Claramunt B, Dax T, Jelen I, Kanka R, Katsoulakos N, Le Roux G, Price M, Scheurer T, Weingartner R (2016) Mountains for Europe‘s Future - A strategic research agenda. The Mountain Research Initiative, Institute of Geography, Bern University and Institute of Interdisciplinary Mountain Research, Austrian Academy of Sciences: http://www.chatmountainalliance.eu/images/Mountains_for_Europes_Future_04_16_d.pdf EEA (2010) Europe's ecological backbone: recognizing the true value of our mountains. EEA (2001) Environmental Signals 2001. Copenhagen: European Environment Agency.

EEA Report 6/2010. European Environmental Agency, Copenhagen: http://www.eea.europa.eu/publications/europes-ecological-backbone Escobar A (2015) Degrowth, postdevelopment, and transitions: a preliminary conversation. Sustain Sci 10: 451-462. doi:10.1007/s11625-015-0297-5

Gallopín G (2015) "Global Scenarios: Explorations in the Scientific Imagination," Great Transition Initiative (April 2015), http://www.greattransition.org/publication/globalscenarios-explorations-in-the-scientific-imagination.

Goodin RE (2010) The Oxford Handbook of International Relations. Oxford University Press, Oxford

Grémont M, Houet T (2015) Downscaling socio-economic prospective scenarios with a participatory approach for assessing the possible impacts of future land use and cover changes on the vulnerability of societies to mountain risks. EGU 2015, General Assembly, Apr 2015, Vienna: https://hal-brgm.archives-ouvertes.fr/hal-01143007 
Gutek G (2014) Philosophical, ideological, and theoretical perspectives on education. Pearson, New Jersey

Hajer MA (1995) The politics of environmental discourse: Ecological modernization and the policy process. Oxford University Press, New York

Healey NM (1994) The transition economies of central and eastern Europe: a political, economic, social and technological analysis. Columbia J World Bus 29:62-70.

doi:10.1016/0022-5428(94)90020-5

Heikkinen HI, Sarkki S, Nuttall M (2012) Users or producers of ecosystem services? A scenario exercise for integrating conservation and reindeer herding in northeast Finland. Pastor Res Policy Pract 2:11. doi:10.1186/2041-7136-2-11

Henrichs T, Zurek M, Eickhout B, Kok K, Raudsepp-Hearne C, Ribeiro T, van Vuuren D, Volkery A (2010) Scenario development and analysis for forward-looking ecosystem assessments. In: Ash N, Blanco H, Brown C, Garcia K, Hendrichs T, Lucas N, Raudsepp-Hearne C, Scholes RD, Tomich T, Vira B, Zurek M (eds) Ecosystems and human well-being: A manual for assessment practitioners. Island Press, Washington DC, pp 151-219

Heynen N, McCarthy J, Prudham S, Robbins P (eds) (2007) Neoliberal Environments: False Promises and Unnatural Consequences. Routledge, London and New York Hildebrand DL (2003) The Neopragmatist Turn. SW Phil Rev 19:79-88. doi:10.5840/swphilreview20031918 
Holtmeier FK (2009) Mountain timberlines; ecology, patchiness and dynamics.

Advances in Global Change Research 36, Springer, Berlin. doi:10.1007/978-1-4020$9705-8$

IPCC (2014) Climate Change 2014. Synthesis Report Summary for Policymakers: https://www.ipcc.ch/pdf/assessment-report/ar5/syr/AR5_SYR_FINAL_SPM.pdf Kaivo-Oja J (2016) Towards better participatory processes in technology foresight: How to link participatory foresight research to the methodological machinery of qualitative research and phenomenology? Futures: In Press. doi:10.1016/j.futures.2016.07.004

Kishita Y, Hara K, Uwasu M, Umeda Y (2016) Research needs and challenges faced in supporting scenario design in sustainability science: a literature review. Sustain Sci 11: 331-347. doi:10.1007/s11625-015-0340-6

Kok K, van Vliet M, Bärlund I, Dubel A, Sendzimir J (2011) Combining participative backcasting and exploratory scenario development: Experiences from the SCENES project. Technol Forecast Soc Change 78:835-851. doi:10.1016/j.techfore.2011.01.004 Kok MTJ, Kok K, Peterson GD, Hill R, Agard J, Carpenter SR (2016) Biodiversity and ecosystem services require IPBES to take novel approach to scenarios. Sustain Sci. doi:10.1007/s11625-016-0354-8

Kullman L, Øberg L (2009) Post-little Ice Age tree line rise and climate warming in the Swedish Scandes; A landscape ecological perspective. J Ecol 97:415-429. doi:10.1111/j.1365-2745.2009.01488.x 


\begin{abstract}
Kupfer JA, Cairns DM (1996) The suitability of montane ecotones as indicators of global climatic change. Prog Phys Geog 20:253-272.

doi:10.1177/030913339602000301
\end{abstract}

Kyriazopoulos A, Abraham E, Hofgaard A, Sarkki S (2014) DPSIR for treeline ecosystem and their services. Progress Report COST Action ES1203:

www.cost.eu/sensfor

Latour B (1987) Science in action: how to follow scientists and engineers through society. Harvard University Press, Cambridge, Massachusetts

Lindo Systems Inc. 2012 "What's Best” ${ }^{\circledR}$ Version 12.0.1.5. Excel add-in for linear, non-linear, and integer modeling.

LIPSOR (2016) La prospective. The Laboratory for Investigation in Prospective Strategy and Organization. Methods of prospective. MICMAC, MACTOR, Scenaring tools, SMIC PROB-EXPERT, Color Insight, MULTIPOL. http://en.laprospective.fr/methods-of-prospective.html (15. 9. 2016)

Lord S, Helfgott A, Vervoort JM (2016) Choosing diverse sets of plausible scenarios in multidimensional exploratory futures techniques. Futures 77: 11-27. doi:10.1016/j.futures.2015.12.003

MA (2005) Millennium Ecosystem Assessment. Ecosystems and human well-being, Vol 2, Scenarios, Ecosystems and human wellbeing. Island Press, Washington DC Moore CM, Longo G, Palmer P (1999) Visioning. In: Susskind T, McKearnan S, Thomas-Larmer J (eds) The Consensus Building Handbook: A Comprehensive Guide to Reaching Agreement, SAGE Publications Inc, Thousand Oaks, California, pp. 557-590 
Mottet A, Ladet S, Coqué N, Gibon A (2006) Agricultural land-use change and its drivers in mountain landscapes: A case study in the Pyrenees. Agric Ecosyst Environ 114:296-310. doi:10.1016/j.agee.2005.11.017

Mountain Agenda (2002) Mountains of the world. Sustainable development in mountain areas. The need for adequate policies and instruments. Buri Druck AG, Berne: https://www.cbd.int/doc/case-studies/tttc/tttc-00170-en.pdf

Nelson N, Geltzer A, Hilgartner S (2008) Introduction: The anticipatory state: Making policy-relevant knowledge about the future. Sci Public Policy 35:546-550. doi:10.3152/030234208X370648

Niemeijer D, de Groot RS (2008) Framing environmental indicators: moving from causal chains to causal networks. Environment, Development and Sustainability 10: 89106. doi:10.1007/s10668-006-9040-9

Oteros-Rozas E, Martín-López B, Daw T, Bohensky E, Butler J, Hill R, Martin-Ortega J, Quinlan A, Ravera F, Ruiz-Mallén I, Thyresson M, Mistry J, Palomo I, Peterson GD, Plieninger T, Waylen KA, Beach D, Bohnet IC, Hamann M, Hanspach J, Hubacek K, Lavorel S, Vilardy S (2015) Participatory scenario planning in place-based socialecological research: insights and experiences from 23 case studies. Ecol Soc 20:32. doi:10.5751/ES-07985-200432

O’Neill BC, Kriegler E, Ebi KL, Kemp-Benedict E, Riahi K, Rothman DS, Van Ruijven B, Van Vuuren D, Birkmann J, Kok K, Levy M, Moss R, Solecki W (2015) The Roads Ahead: Narratives for Shared Socioeconomic Pathways describing World Futures in the 21st Century. Global Environ Chang. doi:10.1016/j.gloenvcha.2015.01.004. 
Pielke RA (2007) The Honest Broker. Making Sense of Science in Policy and Politics. Cambridge University Press, Cambridge

Raskin P, Banuri T, Gallopín G, Gutman P, Hammond A, Kates R, Swart R (2002)

Great transition: The promise and lure of the times ahead. A report of the global scenario group. Stockholm Environment Institute, Stockholm

Raskin P, Monks F, Ribeiro T, van Vuuren D, Zurek MB (2005) Global scenarios in historical perspective. In: Carpenter SR, Pingali PL, Bennett EM, Zurek MB (eds) Ecosystems and human wellbeing: Scenarios, Vol 2: Findings of the scenarios working group of the Millennium Ecosystem Assessment. Island Press, Washington DC, pp. 3544

Raskin PD, Electris,C, Rosen RA (2010) The Century Ahead: Searching for Sustainability. Sustainability 2:2626-2651. doi:10.3390/su2082626

Roth S, Kaivo-Oja J (2015) Is the future a political economy? Functional analysis of three leading foresight and futures studies journals. Futures 81:15-26. doi:10.1016/j.futures.2015.10.002

Roth S (2016) Growth and function. A viral research program for next organisations. International Journal of Technology Management (in press).

Roudometof V (2015) The Glocal and Global Studies. Globalizations 12:774-787. doi:10.1080/14747731.2015.1016293

Rounsevell MDA, Dawson TP, Harrison PA (2010) A conceptual framework to analyse the effects of environmental change on ecosystem service. Biodivers Conserv 19:28232842. doi:10.1007/s10531-010-9838-5 
Sarkki S, Ficko A, Grunewald K, Nijnik M (2016) Benefits from and threats to European treeline ecosystem services: An exploratory study of stakeholders and governance. Reg Environ Change 16: 2019-2032. doi:10.1007/s10113-015-0812-3

Sarkki S, Grunewald K, Nijnik M, Zahvoyska L, Abraham EM, Alados CL, Bellamy C, Bratanova-Dontcheva S, Jokinen M, Kollar J, Krajčí J, Kyriazopoulos AP, Monteiro AT, Munoz-Rojas J, Parpan T, Sing L, Smith M, Sutinen ML, Tolvanen A, Zhyla T (2015) SENSFOR Deliverable 4. Problems and proposals for good environmental management: Empirical assessment of European treeline areas: http://www.sensforcost.eu/images/Deliverable\%204.pdf

Schmid E, Sinabell F, Hofreither MF (2007) Phasing out of environmentally harmful subsidies: Consequences of the 2003 CAP reform. Ecol Econ 60:596604.doi:10.1016/j.ecolecon.2005.12.017

Seppelt R, Lautenbach S, Volk M (2013) Identifying trade-offs between ecosystem services, land use, and biodiversity: a plea for combining scenario analysis and optimization on different spatial scales. Current Opinion in Environmental Sustainability 5: 458-463. doi:10.1016/j.cosust.2013.05.002

Smith WK, Germino MJ, Hancock TE, Johnson DM (2009) The altitude of alpine treeline; a bellwether of climate change effects. Bot Rev 75:163-190. doi:10.1007/s12229-009-9030-3

Stirling A (2010) Keep it complex. Nature 468:1029-1031. doi:10.1038/4681029a Tellus Institute (2016) Quantitative simulations. http://www.tellus.org/integratedscenarios/quantitative-simulations (1.6. 2016) 
Turnhout E, Dewulf A, Hulme M (2016) What does policy-relevant global environmental knowledge do? The cases of climate and biodiversity. Curr Opin Environ Sustain 18:65-72. doi:10.1016/j.cosust.2015.09.004

UNEP (2007) Global Environment Outlook 4. Environment for Development, UNEP, Nairobi: http://www.unep.org/geo/geo4.asp

Van der Sluijs JP (2005) Uncertainty as a monster in the science-policy interface: four coping strategies. Water Sci Technol 52:87-92.

van Vliet, M., K. Kok, T. Veldkamp, \& S. Sarkki. 2012. Structure in creativity; An exploratory study to analyse the effects of structuring tools on scenario workshop results. Futures 44(8): 746-760. doi:10.1016/j.futures.2012.05.002

Vervoort J, Thornton PK, Kristjansson P, Foerch W, Ericksen PJ, Kok K, Ingram JS Herrero M, Palazzo A, Helfgott AES, Wilkinson A, Havlik P, Mason-D'Croz D, Jost C (2014) Challenges to scenario-guided adaptive action on food security under climate change. Global Environ Chang 28:383-394. doi:10.1016/j.gloenvcha.2014.03.001 Wilkinson A (2009) Scenarios practices: in search of theory. J Futur Stud 13:107-114. Zurek MB, Henrichs T (2007) Linking scenarios across geographical scales in international environmental assessments. Technol Forecast Soc Change 74:1282-1295. doi:10.1016/j.techfore.2006.11.005

\section{Tables:}


Table 1. Four scenarios for the future of European treeline areas and the key variables describing the scenarios

\begin{tabular}{|c|c|c|c|c|}
\hline Key variables & $\begin{array}{l}\text { "Global } \\
\text { Markets" }\end{array}$ & $\begin{array}{l}\text { "Self-sufficient } \\
\text { Economies" }\end{array}$ & $\begin{array}{l}\text { "Tyranny of } \\
\text { Climate } \\
\text { Governance" }\end{array}$ & $\begin{array}{l}\text { "Sustainable Use } \\
\text { of Ecosystem } \\
\text { Services" }\end{array}$ \\
\hline Transport & $\begin{array}{l}\text { Global travel } \\
\text { increases and } \\
\text { fossil fuels are } \\
\text { used }\end{array}$ & $\begin{array}{l}\text { Fossil fuels are } \\
\text { used, but global } \\
\text { travel declines. } \\
\text { Local mobility } \\
\text { systems }\end{array}$ & $\begin{array}{l}\text { Alternative fuel } \\
\text { deployment, air } \\
\text { travel in strong } \\
\text { decline }\end{array}$ & $\begin{array}{l}\text { Greener and } \\
\text { climate friendly } \\
\text { logistic systems, } \\
\text { multimodal } \\
\text { ticketing }\end{array}$ \\
\hline Food production & $\begin{array}{l}\text { Food comes } \\
\text { from global } \\
\text { markets, price } \\
\text { competition } \\
\text { dominates }\end{array}$ & $\begin{array}{l}\text { National food } \\
\text { production is } \\
\text { heavily } \\
\text { subsidized and } \\
\text { supported in } \\
\text { mountain areas }\end{array}$ & $\begin{array}{l}\text { National and } \\
\text { regional climate- } \\
\text { neutral products } \\
\text { are used }\end{array}$ & $\begin{array}{l}\text { Sustainability of } \\
\text { food production, } \\
\text { imported goods } \\
\text { not in fashion }\end{array}$ \\
\hline Subsidies & $\begin{array}{l}\text { No subsidy } \\
\text { support for } \\
\text { entering into } \\
\text { global markets }\end{array}$ & $\begin{array}{l}\text { Heavily } \\
\text { subsidized food } \\
\text { and energy } \\
\text { production to } \\
\text { ensure self- } \\
\text { sufficiency of } \\
\text { treeline areas }\end{array}$ & $\begin{array}{l}\text { Resources } \\
\text { allocated to } \\
\text { climate change } \\
\text { adaptation and } \\
\text { mitigation }\end{array}$ & $\begin{array}{l}\text { Small-scale and } \\
\text { green energy } \\
\text { and food } \\
\text { production } \\
\text { solutions } \\
\text { subsidized }\end{array}$ \\
\hline $\begin{array}{l}\text { Energy } \\
\text { production }\end{array}$ & $\begin{array}{l}\text { Energy is } \\
\text { produced in the } \\
\text { cheapest way } \\
\text { and location, } \\
\text { fossil fuels } \\
\text { heavily utilized }\end{array}$ & $\begin{array}{l}\text { All forms of } \\
\text { energy } \\
\text { production } \\
\text { maximized } \\
\text { within states } \\
\text { and EU }\end{array}$ & $\begin{array}{l}\text { Only climate } \\
\text { friendly } \\
\text { solutions are } \\
\text { used including } \\
\text { nuclear power }\end{array}$ & $\begin{array}{l}\text { Emphasis on } \\
\text { green and small- } \\
\text { scale energy } \\
\text { production }\end{array}$ \\
\hline $\begin{array}{l}\text { Governance and } \\
\text { policy }\end{array}$ & $\begin{array}{l}\text { Weak national } \\
\text { policies }\end{array}$ & $\begin{array}{l}\text { National level } \\
\text { policies prevail }\end{array}$ & $\begin{array}{l}\text { Global top-down } \\
\text { policies }\end{array}$ & $\begin{array}{l}\text { Balanced multi- } \\
\text { level governance }\end{array}$ \\
\hline $\begin{array}{l}\text { Role of science in } \\
\text { governance }\end{array}$ & $\begin{array}{l}\text { Innovation } \\
\text { platforms with } \\
\text { science and } \\
\text { market actors }\end{array}$ & $\begin{array}{l}\text { Multi-level } \\
\text { optimization to } \\
\text { maintain } \\
\text { national growth }\end{array}$ & $\begin{array}{l}\text { Technocracy } \\
\text { dominated by } \\
\text { global climate } \\
\text { science }\end{array}$ & $\begin{array}{l}\text { Adaptive co- } \\
\text { management } \\
\text { between policy, } \\
\text { stakeholders and } \\
\text { science }\end{array}$ \\
\hline Markets & $\begin{array}{l}\text { Global } \\
\text { unregulated } \\
\text { markets }\end{array}$ & $\begin{array}{l}\text { Circular } \\
\text { economy }\end{array}$ & $\begin{array}{l}\text { Climate } \\
\text { mitigation } \\
\text { policies }\end{array}$ & $\begin{array}{l}\text { Globally } \\
\text { connected but } \\
\text { regulated for } \\
\text { sustainability. }\end{array}$ \\
\hline $\begin{array}{l}\text { Worldview on } \\
\text { environmental } \\
\text { problems }\end{array}$ & $\begin{array}{l}\text { Reactive: action } \\
\text { taken after } \\
\text { problems } \\
\text { appear }\end{array}$ & $\begin{array}{l}\text { Only recognized } \\
\text { when they link } \\
\text { to security and } \\
\text { national self- } \\
\text { sufficiency }\end{array}$ & $\begin{array}{l}\text { Climate change } \\
\text { is the No } 1 \\
\text { problem }\end{array}$ & $\begin{array}{l}\text { Proactive view } \\
\text { and use of the } \\
\text { precautionary } \\
\text { principle }\end{array}$ \\
\hline $\begin{array}{l}\text { Treeline area } \\
\text { perception }\end{array}$ & $\begin{array}{l}\text { Interesting } \\
\text { tourism } \\
\text { destinations }\end{array}$ & $\begin{array}{l}\text { Underused } \\
\text { resources for } \\
\text { national } \\
\text { economies }\end{array}$ & $\begin{array}{l}\text { Icons to be } \\
\text { safeguarded }\end{array}$ & $\begin{array}{l}\text { Multi-functional } \\
\text { landscapes }\end{array}$ \\
\hline
\end{tabular}


Table 2. Negative (-) and positive (+) implications of the scenario storylines on the four dimensions of sustainability for European treeline areas

\begin{tabular}{|c|c|c|c|c|}
\hline $\begin{array}{l}\text { Dimension of } \\
\text { sustainability }\end{array}$ & Global markets & $\begin{array}{l}\text { Self-sufficient } \\
\text { economies }\end{array}$ & $\begin{array}{l}\text { Tyranny of } \\
\text { climate } \\
\text { governance }\end{array}$ & $\begin{array}{l}\text { Sustainable use of } \\
\text { ecosystem } \\
\text { services }\end{array}$ \\
\hline $\begin{array}{l}\text { Environmental } \\
\text { sustainability }\end{array}$ & $\begin{array}{l}\text { (-) Ecological } \\
\text { values in } \\
\text { treeline } \\
\text { ecosystems are } \\
\text { accounted for } \\
\text { only if they } \\
\text { possess } \\
\text { economic value } \\
(+) \text { Less } \\
\text { productive } \\
\text { treeline areas } \\
\text { are of no } \\
\text { interest to } \\
\text { industrial } \\
\text { stakeholders }\end{array}$ & $\begin{array}{l}\text { (-) Environmental } \\
\text { problems are } \\
\text { only recognized } \\
\text { when they link to } \\
\text { security or self- } \\
\text { sufficient } \\
\text { economy } \\
\text { (+) Decline of } \\
\text { unsustainable } \\
\text { global } \\
\text { transportation of } \\
\text { people, goods } \\
\text { and services, less } \\
\text { migrations }\end{array}$ & $\begin{array}{l}\text { (-) Climate } \\
\text { change is the } \\
\text { only recognized } \\
\text { environmental } \\
\text { problem } \\
(+) \text { Acknowledges } \\
\text { links between } \\
\text { ecological } \\
\text { sustainability and } \\
\text { climate change in } \\
\text { treeline areas }\end{array}$ & $\begin{array}{l}\text { (-) Stronger focus } \\
\text { on ecological } \\
\text { values with } \\
\text { market value } \\
\text { (+) Proactive } \\
\text { regulations to } \\
\text { prevent negative } \\
\text { environmental } \\
\text { impacts }\end{array}$ \\
\hline $\begin{array}{l}\text { Economic } \\
\text { sustainability }\end{array}$ & $\begin{array}{l}\text { (-) Markets } \\
\text { promote } \\
\text { industrial land- } \\
\text { use having } \\
\text { negative } \\
\text { impacts on } \\
\text { other land } \\
\text { users } \\
\text { (+) Connections } \\
\text { to global } \\
\text { markets } \\
\text { increase } \\
\text { economic } \\
\text { benefits }\end{array}$ & $\begin{array}{l}\text { (-) Treeline } \\
\text { stakeholders } \\
\text { without link to } \\
\text { strong economic } \\
\text { activities will } \\
\text { perish } \\
\text { (+) Production of } \\
\text { goods in treeline } \\
\text { areas is strongly } \\
\text { subsidized }\end{array}$ & $\begin{array}{l}\text { (-) Strict } \\
\text { regulation of } \\
\text { markets may } \\
\text { hinder economic } \\
\text { opportunities } \\
\text { (+) Markets for } \\
\text { climate } \\
\text { mitigation and } \\
\text { resources for } \\
\text { adaptation }\end{array}$ & $\begin{array}{l}\text { (-) Normative } \\
\text { sustainability } \\
\text { goals may hinder } \\
\text { markets } \\
\text { (+) Less market } \\
\text { failures, new } \\
\text { economic } \\
\text { opportunities }\end{array}$ \\
\hline $\begin{array}{l}\text { Social } \\
\text { Sustainability }\end{array}$ & $\begin{array}{l}\text { (-) Democratic } \\
\text { decision making } \\
\text { is overrun by } \\
\text { markets } \\
(+) \text { By engaging } \\
\text { in markets } \\
\text { treeline } \\
\text { stakeholders } \\
\text { can detour } \\
\text { policy } \\
\text { hierarchies }\end{array}$ & $\begin{array}{l}\text { (-) Treeline land } \\
\text { use policy } \\
\text { tailored to } \\
\text { dominant } \\
\text { industrial actors } \\
\text { (+) Domestic and } \\
\text { local economic } \\
\text { interest in } \\
\text { treeline areas are } \\
\text { priority }\end{array}$ & $\begin{array}{l}\text { (-) Technocracy } \\
\text { dominates the } \\
\text { governance } \\
(+) \text { Scientists and } \\
\text { citizen scientists } \\
\text { are monitoring } \\
\text { climate change } \\
\text { impacts in } \\
\text { treeline areas }\end{array}$ & $\begin{array}{l}(-) \text { The } \\
\text { compromises } \\
\text { between treeline } \\
\text { stakeholders may } \\
\text { satisfy nobody } \\
(+) \text { Collaborative } \\
\text { governance } \\
\text { engages treeline } \\
\text { stakeholders }\end{array}$ \\
\hline
\end{tabular}




\begin{tabular}{lllll}
\hline Cultural & (-) Respect for & $(-)$ Maintaining & $(-)$ Places climate & $(-)$ Negative \\
sustainability & treeline cultural & cross cultural & neutrality above & environmental \\
& values is & dialogue is a & culturally & impacts of \\
& replaced by & challenge & important & traditional land \\
& aims for cost- & $(+)$ Treeline & livelihoods & uses are not \\
& efficiency. & traditional & $(+)$ Educates & tolerated \\
& $(+)$ Cultural & livelihoods and & citizens about the & $(+)$ Local cultural \\
& values may & related products & impacts of & values are \\
diffuse via & are valued & climate change & respected as \\
global & & by using treeline & equal when \\
& movement of & & areas as & compared to \\
& treeline goods & & indicators & other interests on \\
& and services & & & ecosystem \\
& & & & services \\
\hline
\end{tabular}




\section{List of Figure legends}

Fig. 1. Europe's mountain massifs with the number of case studies used for the development of the treeline area scenarios (adapted after EEA, 2010).

Fig. 2. The workflow diagram in scenario production and evaluation.

Fig. 3. Four scenarios for the future of European treeline areas ordinated in a climate change - land use matrix

Fig. 4. "Reduction" and "rhetorical packaging" in the DPSIR framework for studying treeline area pastoralism (white background) and more contextual mapping of key factors explaining future changes in treeline area pastoralism (grey background). The arrows between boxes illustrate feedbacks that can be positive (+) or negative (-).

Fig. 5. Four scenarios for the development of key variables in European treeline areas with the pragmatic space in which the scenario users can choose trajectories that best fit pre-existing policy agendas and scientific narratives and maintain the legitimacy of climate-sensitive and economic growth-oriented policies. 


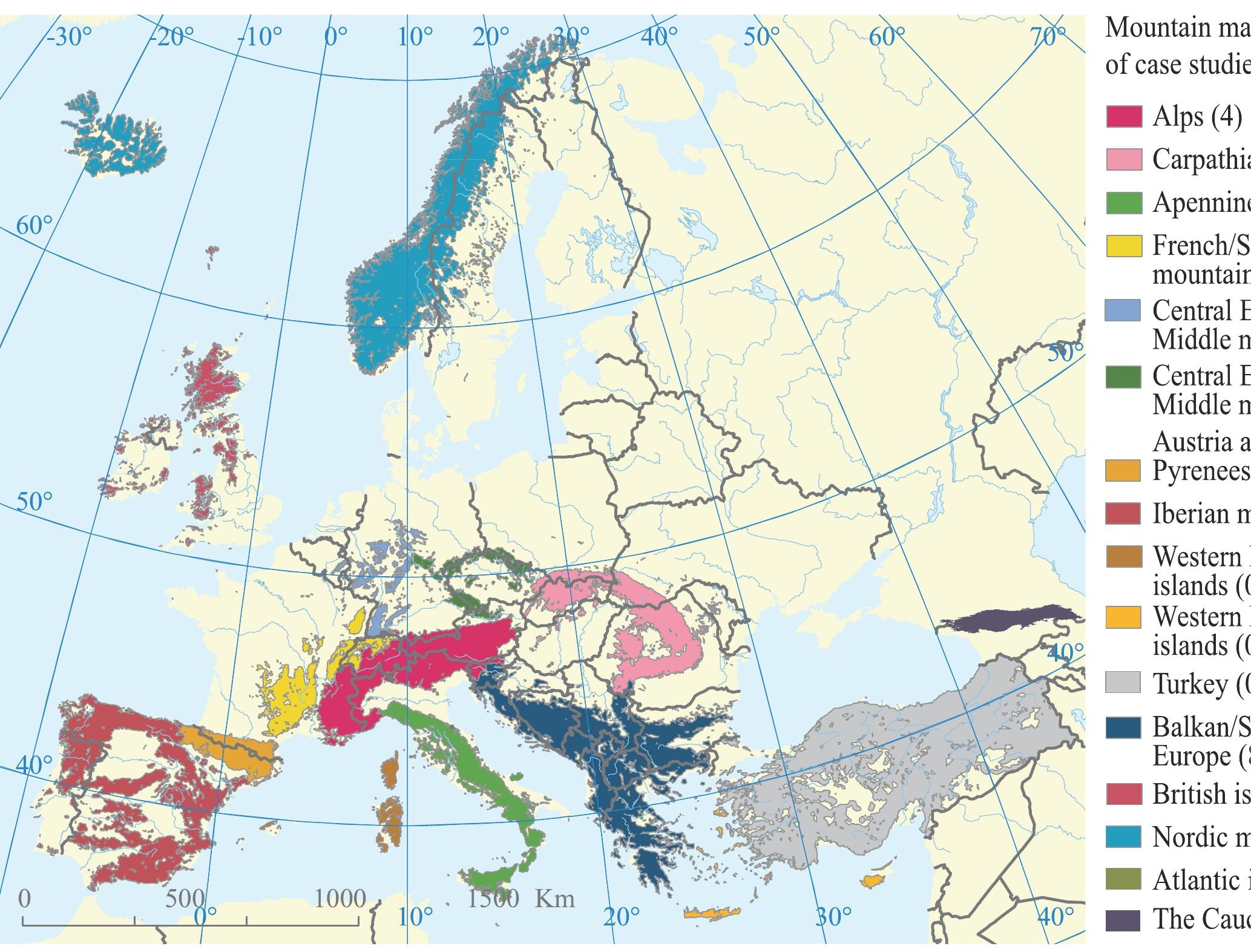




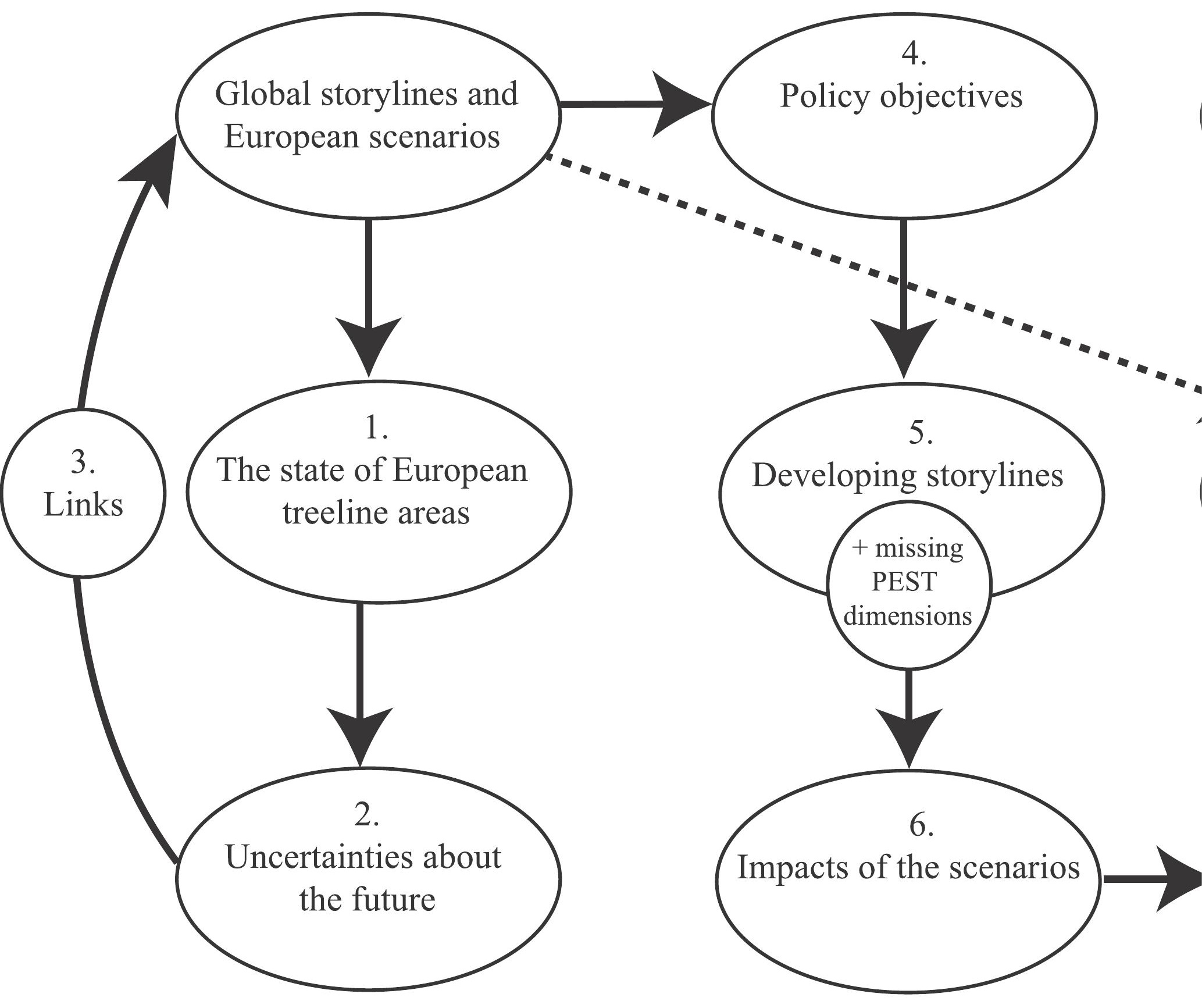




\section{High climate change}

\section{"Global markets"}

Low land use

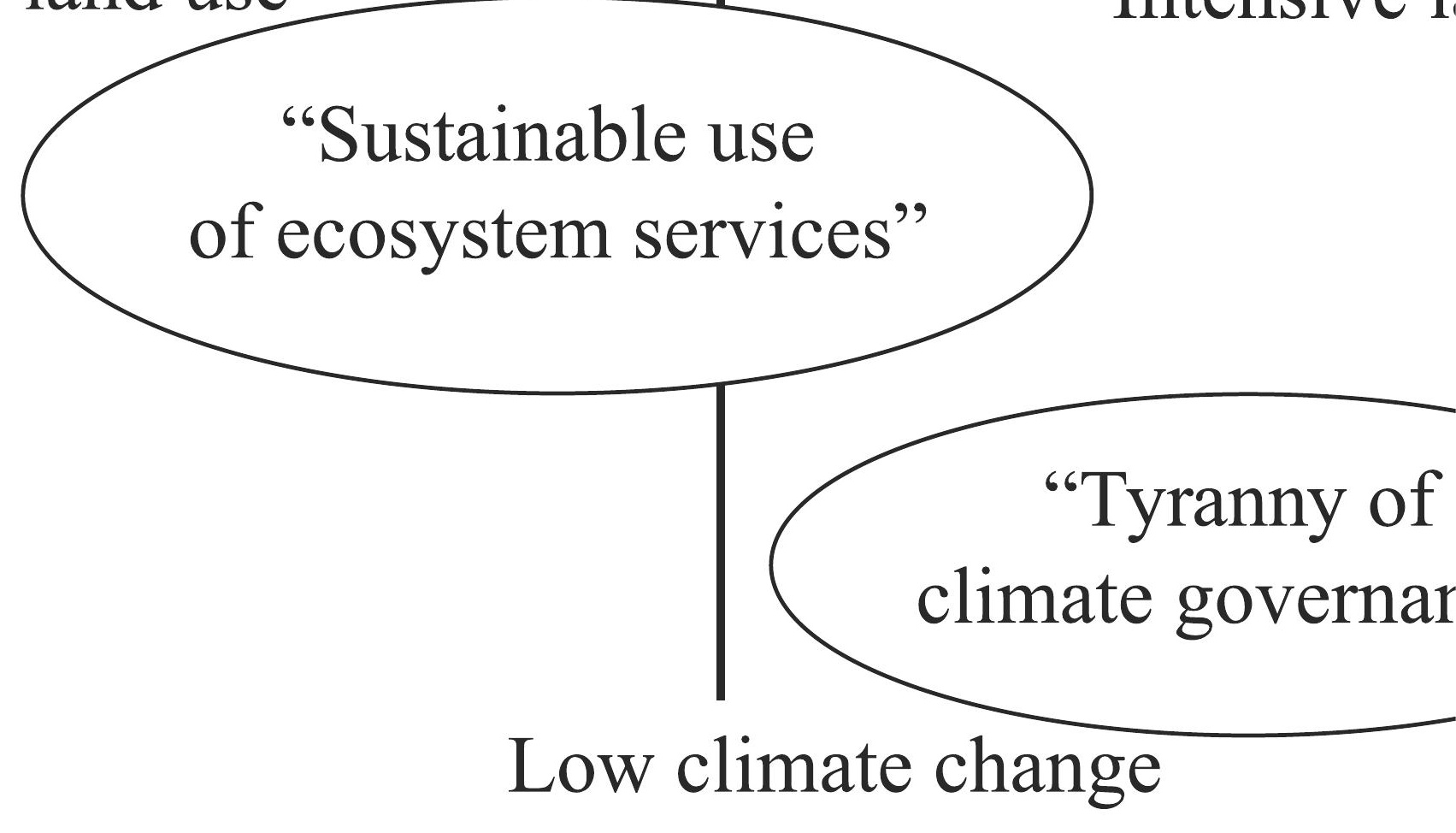

Intensive 1

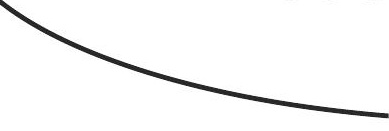


Drivers

Pressures

State

Impacts

$\ominus$

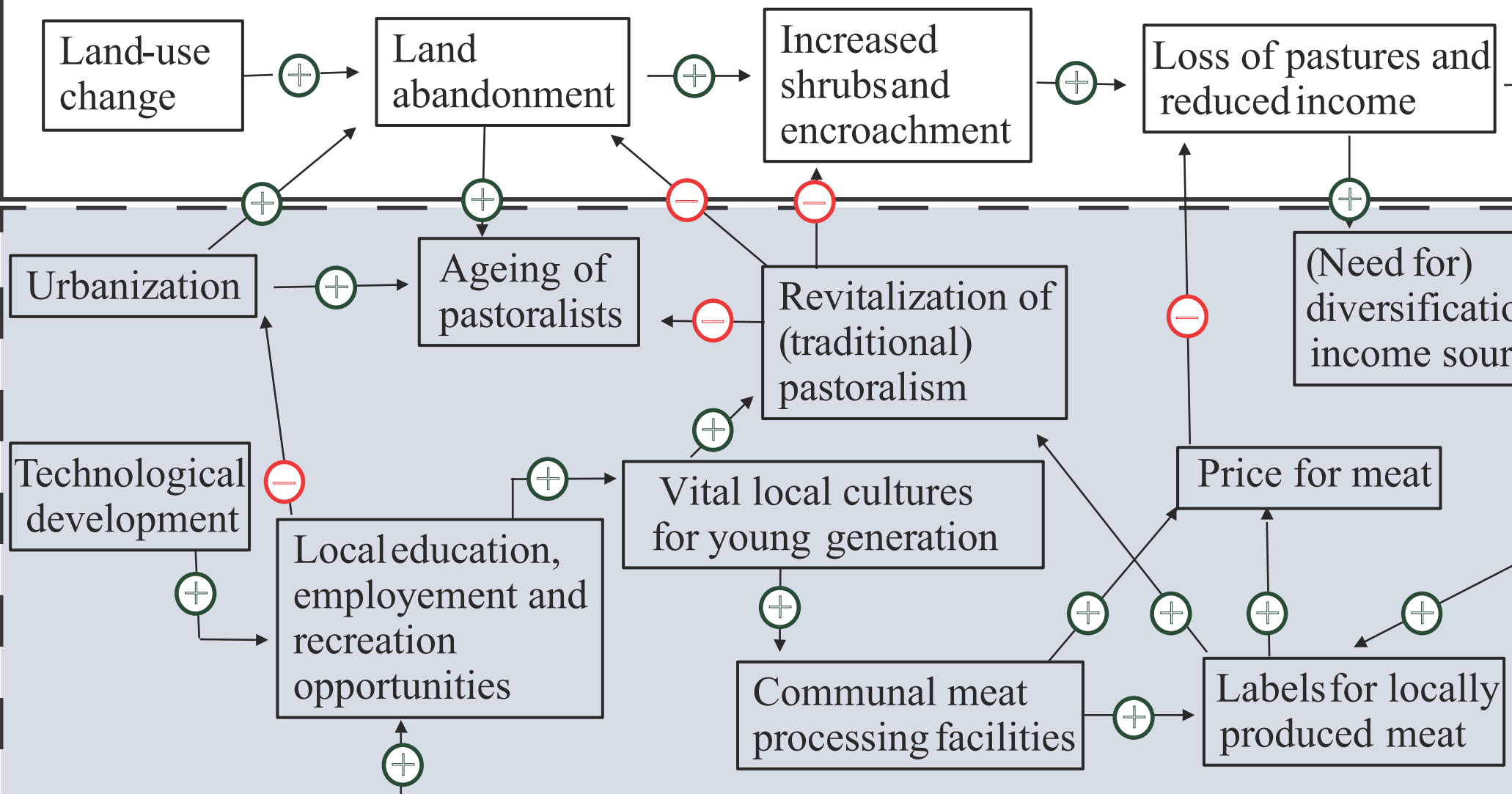

Rural development policies 

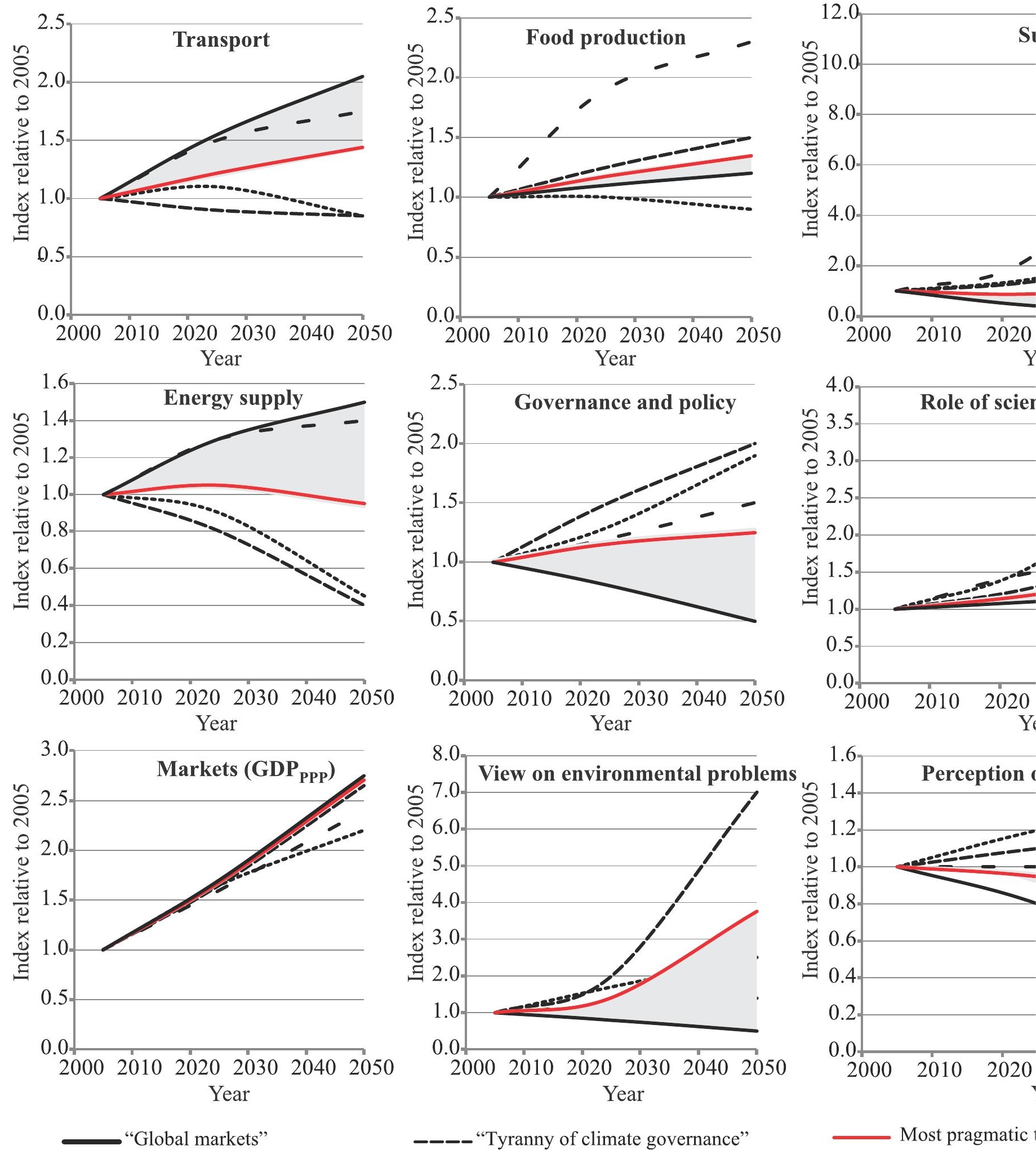

_ _ "Self-sufficient economies"

- - "Tyranny of climate governance"

........ "Sustainable use of ecosystem services"
Most pragmatic Pragmatic space and "Tyranny of 


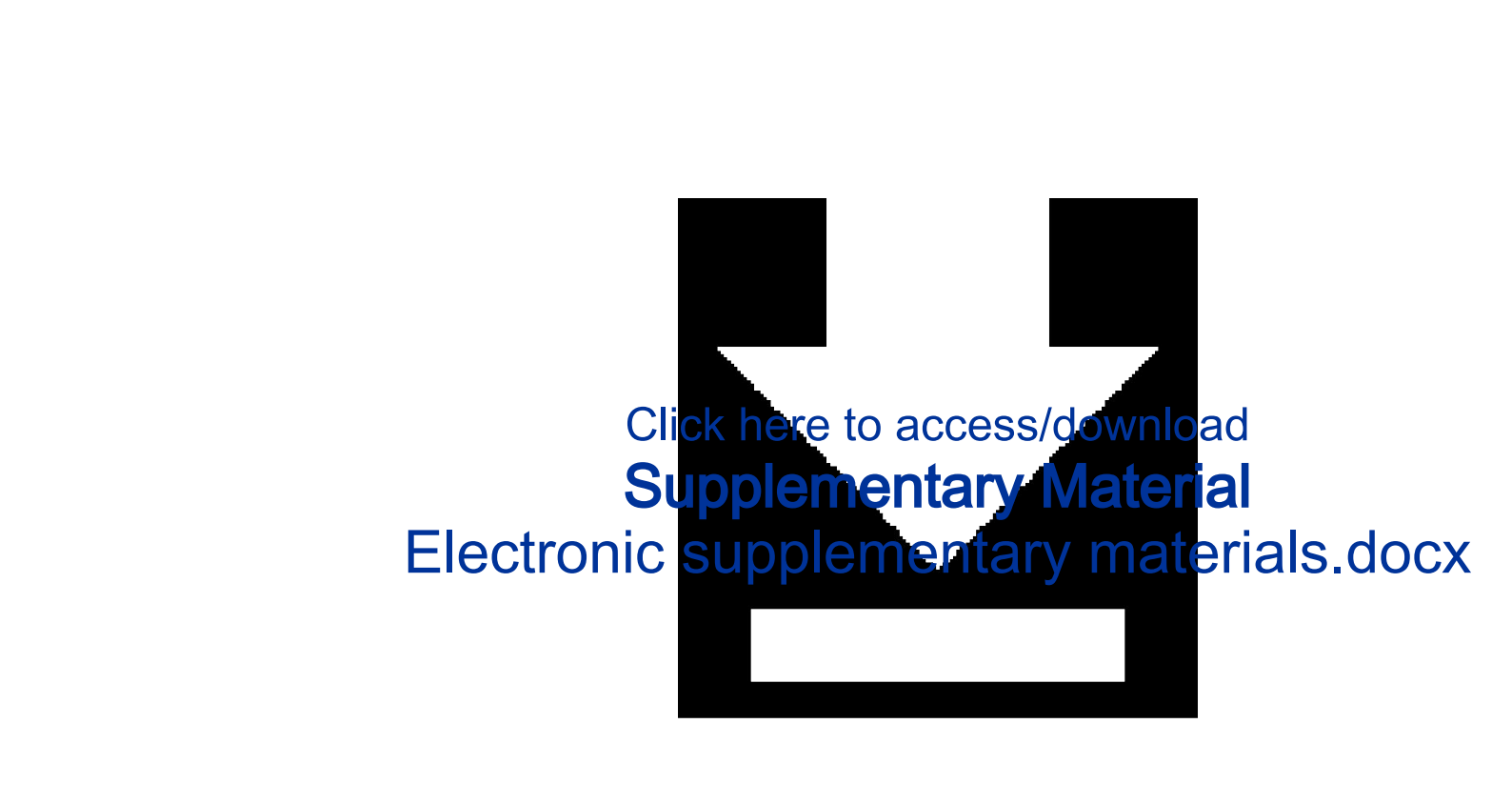

Electronic Supplementary Material

.

